\title{
Growth Performance, Nutrient Digestibility and Economy of Rabbits Fed Varying Dietary Levels of Cameroon Pepper Fruit Meal
}

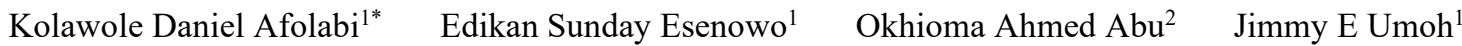 \\ 1.Department of Animal Science, University of Uyo, Uyo, Akwa Ibom State, 520003, Nigeria \\ 2. Department of Animal Science, University of Ibadan, Ibadan, Nigeria
}

\begin{abstract}
Thirty six (36) weanling crossbred male rabbits (Chinchilla x New Zealand) with an average weight of $0.85 \mathrm{~kg}$ were allotted in a CRD to four experimental diets $(16.55 \% \mathrm{CP}$ and $2650 \mathrm{kcal} \mathrm{ME} / \mathrm{kg})$ or treatments and fed ad libitum for 12 weeks. Each treatment comprised of 9 rabbits in 3 replicates of three rabbits each. Treatments or diets 2, 3 and 4 contained $0.1,0.2$ and $0.3 \%$ Cameroon Pepper Fruit Meal (CPFM) respectively while Treatment/Diet 1 without CPFM (0\%) served as the control. The Rabbits were housed in a three-tier iron hutch $(65 \mathrm{~cm} \times 66 \mathrm{~cm} \times 52 \mathrm{~cm})$. The daily weight gain, final body weight, feed efficiency and digestibility of dry matter, ether extract and crude fibre were similar $(\mathrm{p}>0.05)$ across treatments meaning that CPFM had no negative effect on these parameters. Daily feed intake $(69.10-89.07 \mathrm{~g})$ and protein intake $(11.45-14.75 \mathrm{~g})$, feed conversion ratio $(6.38-9.98)$, protein efficiency ratio $(1.39-1.82)$, metabolizable energy intake $(177.12-228.03 \mathrm{kcal} / \mathrm{kg})$, cost of feed intake per rabbit (N651.47 - 820.05), cost of feed intake per kg body weight gain (N710.74 - 1093.81) and digestibility of crude protein $(77.75-84.54 \%)$ varied significantly $(\mathrm{p}<0.05)$ across treatments. Feeding crossbred weaner rabbits with diets containing up to $0.3 \%$ CPFM elicited optimum growth performance with the highest value for weight gain, final body weight, protein intake, digestibility of protein, protein efficiency ratio and efficiency of feed utilization; and a corresponding least value for feed conversion ratio and cost of feed per $\mathrm{kg}$ body weight gain.
\end{abstract}

Keywords: Rabbit, Cameroon pepper, Performance, Economy, Digestibility

DOI: $10.7176 / \mathrm{JBAH} / 9-24-06$

Publication date: December $31^{\text {st }} 2019$

\section{Introduction}

Shortage of protein in the diets of average Nigerians because of shortage in meat supply, high meat price and poverty has led to malnutrition and other nutrition related diseases that lower general human productivity and development in Africa. This warrants the exploration of protein supply from minilivestock like rabbit and the need to promote its performance and productivity by harnessing locally available organic or herbal growth promoter like Cameroon pepper.

Rabbits (Oryctalagus cuniculis L.) are herbivores that has been domesticated for human use as a fast and cheap source of meat protein due to its fecundity, prolificacy, rapid growth rate, docility, small body size, low cost of production as it require small initial capital, and ability to utilize and convert forage and agricultural by-products to meat within short period of time besides others. Rabbit provides inexpensive source of meat that is low in cholesterol and fat, high in protein compared with beef, mutton and pork (Oguike and Ohaja, 2009; Abu et al., 2008). Rabbit appears to be the most suitable means of producing high animal protein for the expanding population of the lesser developed countries and to correct malnutrition especially after war, socio-cultural and politically motivated disturbances, and post- natural disaster era.

Pepper had been reported (Afolabi et al., 2017; Al-kassie et al., 2011) to be very high in some key vitamins such as vitamins $A$, the $B$ vitamin complex, vitamin $C$, vitamin $K$, niacin and minerals like calcium, iron, potassium and manganese. Its high concentration of potassium is highly beneficial for the heart. Cameroon pepper is a type of hot pepper that is common the Cross Rivers, Akwa Ibom and River states of Nigeria where few quantities were produced and bulk of the Cameroon pepper consumed in these areas comes from Cameroon, hence the name Cameroon pepper. Cameroon pepper is hotter than any other pepper and therefore small quantity of it is needed in cooking.

Frequent pungency or hotness which is the most important flavour traits in pepper is a characteristic of the genus capsicum and it is due to an alkaloid compound known as Capsaicinoids that are unique to capsicum (Kraft et al.., 2014; Rodriguez et al., 2010; Fattori et al., 2006). The Capsaicinoids are commonly called capsaicin because it is the most prevalent among the Capsaicinoids followed by Dihydrocapsaicin, Nornordihydrocapsaicin, Homocapsaicin; and Homodihydrocapsaicin that are considered the minor Capsaicinoids (Bosland, 1996).

Capsaicinoids, and capsaicin had been reported to possess a wide range of biological and physiological activities that enable them to function as antioxidants (Bertão et al., 2016; Materska and Peruka, 2005), anticarcinogenics (Macho et al, 2003), antimicrobial, anti-inflammatory and antitumor, besides its contribution to 
the control of diabetes and relieve of pain and symptoms of migraines, colds, psoriasis and kidney disorders (Das et al., 2018; LV et al, 2015; Carlos et al., 2011). Capsaicinoids, and capsaicin also promotes energy metabolism and suppress fat accumulation (Sancho et al; 2002; Ohnuki et al; 2001). The health benefits of pepper has been reported (LV et al, 2015) to include its possession of anti-irritant properties, ability to aid in breaking up and moving or clearing congested mucus, anti-fungal properties, prevents migraine headache, aid digestion (it stimulates the digestive tract, increasing the flow of enzyme production and gastric juices that aids in metabolizing food and toxins), helpful for relieving intestinal gas by stimulating intestinal peristaltic motion, aiding in both assimilation and elimination. Pepper also stimulate production of saliva, an important component of digestion and maintaining optimal oral health, useful for blood clots and stimulate circulation in the body. It increases the pulse of lymphatic and digestive rhythms. By heating the body, the natural process of detoxification is streamlined. Consumption of pepper relief joint pain, has anti-bacterial properties, promotes longevity (people who eat spicy foods have a $14 \%$ chance of living longer than those that don't) and regular consumption of chili peppers had been aligned with reduced rates of death from respiratory disease, heart problems and cancer (LV et al, 2015). Pepper is an excellent preservative and had been used traditionally to preserve seeds and to prevent food contamination from bacteria. (Wahba, 2007; Omolo et al., 2014).

Cameroon pepper is believed locally to supports weight loss by burning excess fats as it reduce triglycerides and LDL cholesterol levels in obese individuals, promotes heart health, a remedy for toothache, topical remedy as a poultice, to treat snake bites, rheumatism, sores, wounds, and lumbago.

There is dearth of information on the nutritive value and economy of Cameroon pepper fruit meal-based diets in rabbits. The growth performance, economy and digestibility of nutrients by crossbred male weaner rabbits fed varying dietary levels of Cameroon pepper fruit meal were hereby assessed.

\section{Materials and Methods}

\subsection{Experimental site, Source and Management of Rabbits}

The study was conducted at the Rabbitry unit of the Teaching and Research farm of the Department of Animal Science, University of Uyo, Uyo, Akwa Ibom State, Nigeria. The Rabbits used for the study were sourced from reputable farms in Uyo, Itu, Ibiono Ibom, Uruan and Ikono Local Government areas of Akwa Ibom state. Thirty six (36) weanling crossbred male rabbits (Chinchilla $\mathrm{x}$ New Zealand) with an average weight of $0.85 \mathrm{~kg}$ were used for the study. The Rabbits were housed in a three-tier iron hutch. Each tier was made up of four cells measuring $65 \mathrm{~cm} \times 66 \mathrm{~cm} \times 52 \mathrm{~cm}$ with three Rabbits per cell. The Rabbits were quarantined for two weeks within which they were treated with prophylactic doses of antibiotics $(1 \mathrm{ml} / \mathrm{kg}$ ), Ivomec (at $0.2 \mathrm{ml} / \mathrm{animal}$ ) and Coccidiostats to get rid of the internal and external parasites. The experimental animals were randomly distributed into four treatments of pelleted Cameroon pepper fruit meal-based diets. Each treatment was replicated three times with three animals per replicate in a Completely Randomized Design (CRD).

\subsection{Procurement of Test Ingredient}

The Cameroon pepper (capsicum annum) fruits were purchased from Akpan Andem market which is not far from the University of Uyo Teaching and Research Farm where the study was carried out. The Cameroon pepper fruits were separated from the stalk remnant contained in the mixture, oven- dried, after which they were ground into powder form and stored in an air tight plastic container in a dry place before use. The Cameroon pepper used contained (AOAC, 2005) moisture, 9\%; protein, 13.4\%; ether extract, $6.8 \%$; ash, 9\%; crude fibre, $11.5 \%$; Nitrogen free extract-NFE, 50.3\%; calcium, $180 \mathrm{mg} / 100 \mathrm{~g}$; Zinc, $0.4 \mathrm{mg} / 100 \mathrm{~g}$; Potassium, 35mg/100g; Magnesium, $75 \mathrm{mg} / 100 \mathrm{~g}$; flavonoids, $1630 \mathrm{mg} / 100 \mathrm{~g}$; B-carotenes, $2235 \mu \mathrm{g} / 100$; Flavonoids $1630 \mathrm{mg} / 100 \mathrm{~g}$.

\subsection{Experimental Diets and Feeding Trials}

The Rabbits used for the study were fed with formulated diets as shown in Table 1. Four experimental diets containing varying levels of Cameroon pepper were formulated, compounded and pelletized. Wheat flour was added to the formulated feed as a binder and the feed were pelletized using pelletizing machine of $0.5 \mathrm{~mm}$ diameter size. The diet containing the treatments comprised of varying percentages of Cameroon pepper of $0 \%$ (control), $0.1 \%, 0.2 \%$ and $0.3 \%$ respectively as shown in 1 below. 
Table 1.Composition of experimental diets containing varying dietary levels of CPFM fed to grower rabbits

\begin{tabular}{lllll}
\hline Treatments/Diets & 1 & 2 & 3 & 4 \\
Levels of CPFM (\%) & 0 & 0.1 & 0.2 & 0.3 \\
\hline Ingredients (\%): & 38.0 & 38.0 & 38.0 & 38.0 \\
Corn & 24.0 & 23.9 & 23.8 & 23.7 \\
Wheat Offal & 2.0 & 2.0 & 2.0 & 2.0 \\
Wheat Flour & 11.2 & 11.2 & 11.2 & 11.2 \\
Soybeans Meal & 21.0 & 21.0 & 21.0 & 21.0 \\
Palm Kernel Cake & - & 0.1 & 0.2 & 0.3 \\
Cameroon Pepper & 3.0 & 3.0 & 3.0 & 3.0 \\
Bone ash & 0.25 & 0.25 & 0.25 & 0.25 \\
Salt & 0.25 & 0.25 & 0.25 & 0.25 \\
*Premix & 0.20 & 0.20 & 0.20 & 0.20 \\
L-Lysine & 0.10 & 0.10 & 0.10 & 0.10 \\
DL-Methionine & $\mathbf{1 0 0}$ & $\mathbf{1 0 0}$ & $\mathbf{1 0 0}$ & $\mathbf{1 0 0}$ \\
Total & & & & \\
Calculated analysis (\%): & 2560 & 2560 & 2560 & 2560 \\
Metabolizable Energy (Kcal/kg) & 16.56 & 16.56 & 16.55 & 16.55 \\
Crude Protein & 4.64 & 4.64 & 4.64 & 4.64 \\
Ether Extract & 9.17 & 9.17 & 9.16 & 9.16 \\
Crude Fibre & 0.95 & 0.95 & 0.95 & 0.95 \\
Calcium & 0.87 & 0.87 & 0.87 & 0.87 \\
Total Phosphorus & 0.96 & 0.96 & 0.96 & 0.96 \\
Lysine & 0.32 & 0.32 & 0.32 & 0.32 \\
Methionine & & & & \\
\hline
\end{tabular}

$\mathrm{CPFM}=$ Cameroon pepper fruit meal.

*Supplied per kg diet: Vit. A, 8 × $10^{6}$; Vit. D3, $1.2 \times 10^{6}$ I.U; Vit.E, 7 × $10^{3} \mathrm{mg}$; Vit. K3, $1.5 \times 10^{3} \mathrm{mg}$; Vit. B1, 2,000 mg; Vit. B2, 2.5 mg; Niacin, 15g; Pantothenic acid, 5.5 g; Vit. B6, 2g; Vit. B12, 10mg; Folic acid, 500mg; Biotin H2, $500 \mathrm{mg}$; Choline chloride, $175 \mathrm{~g}$; Cobalt, $200 \mathrm{mg}$; Copper, $3 \mathrm{~g}$; Iodine, $1 \mathrm{~g}$; Iron, $21 \mathrm{~g}$; Manganese, 40 g; Selenium, $200 \mathrm{mg}$; Zinc, $31 \mathrm{~g}$; Anti-oxidant, $1.25 \mathrm{~g}$.

The feeding trials lasted for twelve (12) weeks, after 14 days of preliminary trials. Feed and water were supplied ad libitum. Parameters measured include the initial body weight, feed intake, weight gain, final body weight, feed conversion ratio, efficiency of feed utilization, daily protein intake, protein efficiency ratio, metabolizable energy intake, cost of feed per kg, cost of feed intake per rabbit, cost of feed intake per kg body weight gain and percentage digestibility of feed nutrients.

Efficiency of Feed Utilization (EFU) is the ratio of body weight gain to feed intake; while daily protein intake is the product of feed intake and the crude protein content of the feed. Protein Efficiency Ratio (PER) is the ratio of daily weight gain to the daily protein intake. Metabolizable Energy (ME) Intake were calculated as ME $/ \mathrm{kg} \times$ feed intake (kg). The costs of feed were calculated based on the current price of ingredients per $\mathrm{kg}$ during the experimental period.

\subsection{Digestibility of nutrients}

The digestibility of feed nutrients was also determined by serving $50 \mathrm{~g}$ of feed per animal per day. Faecal output was collected and weighed after 24 hours of feeding for seven days and oven dried on daily basis to determine the dry matter content. Digestibility of nutrients was then calculated in percentage as Nutrient absorbed $\div$ nutrients in feed $\times 100$. While nutrients absorbed were calculated as nutrient in feed minus the nutrients in faeces.

\subsection{Laboratory analysis}

The proximate composition of dried Cameroon pepper fruit meal, experimental feed and feacal samples were determined (AOAC, 2005) in the laboratory.

\subsection{Statistical Analysis}

Data obtained from the study were subjected to analysis of variance (ANOVA) in a Completely Randomized Design (CRD) and the means were separated with DMRT option of the software. (SPSS, 2013).

\section{Results and Discussion}

Growth performance and economy of rabbits fed varying dietary levels of Cameroon Pepper Fruit Meal (CPFM) is as shown in Table 2 below. The initial body weight $(803.33-916.67 \mathrm{~g})$ of experimental animals that ranged between 803.33 and $916.67 \mathrm{~g}$ were similar. The daily weight gain $(8.67-10.99 \mathrm{~g})$, final body weight $(1531.33-$ 
$1760.03 \mathrm{~g})$, EFU $(0.12-0.16)$ obtained for rabbits in this study were similar $(\mathrm{p}>0.05)$ across treatments meaning that diets with Cameron pepper had no negative effect on these parameters.

Daily Feed Intake (FI) $(69.10-89.07 \mathrm{~g})$ varied significantly. Feeding rabbits with $0.1 \%$ dietary level of CPFM enhanced the daily FI (89.07g/rabbit/day) and was significantly higher than what obtained for those on 0.2 and $0.3 \%$ dietary CPFM. The FI was increased by the stimulating substances (Capsaicin, ascorbic acid and vitamins) in Cameroon pepper; and further increase in the dietary pepper levels/content made the feed to be hotter, pungent, acidic or pepperish which reduced the feed intake. Frequent pungency or hotness which is the most important flavour traits in pepper is a characteristic of the genus capsicum and it is due to an alkaloid compound known as Capsaicinoids that are unique to capsicum (Kraft et al.., 2014; Rodriguez et al., 2010; Fattori et al., 2006). Generally, peppers had been implicated to aid digestion by stimulating the digestive tract which increase the flow of enzyme production and gastric juices that aids in metabolizing food and toxins. It is helpful for relieving intestinal gas by stimulating intestinal peristaltic motion, aiding in both assimilation and elimination. Pepper also stimulate production of saliva, an important component of digestion and maintaining optimal oral health.

Despite the reduction in FI with increasing levels of Cameroon pepper in the diets the weight gain and the final body weights were not significantly different $(p>0.05)$ meaning that the inclusion of the pepper had improved the efficiency of feed utilization by saving the farmer cost of production as a result of reduction in feed intake. This is reflected in the numerical decrease and increase in the FCR and EFU respectively in rabbits fed beyond $0.1 \%$ dietary CPFM. Hencken (1991) explained that pepper is rich in vitamin C, which has a considerable impact on improving production through contributing to the reduction of heat stress. Pawar., et al (2011) also suggested that Capsaicin is an important anti-oxidant that is capable of reducing the feed conversion efficiency of animals. Similarly, Ndelekwute et al., (2015) also reported that live weight, feed intake, weight gain, feed: gain ratio and protein efficiency ratio of broilers were negatively affected by 0.75 and $1.0 \%$ inclusion of dietary black pepper (Piper nigrum) to their feeds.

The daily protein intake $(11.45-14.75 \mathrm{~g})$, metabolizable energy intake $(177.12-228.03)$, FCR $(6.38-9.98)$, cost of FI per kg BWG (N710.74 - 1093.81) of rabbits fed diet with $0.1 \%$ CPFM were similar with those on control diet, but decreased significantly for rabbits fed beyond $0.1 \%$ dietary CPFM. The daily protein intake of rabbits was highest on rabbits fed diet with $0.1 \%$ CPFM $(14.75 \mathrm{~g})$ and significantly lower in rabbits fed diets with 0.2 and $0.3 \%$ CPFM (11.45 and 11.52g respectively) compared to what obtained for rabbits on control diet (12.58g). This implies that CPFM positively influenced the protein intake of rabbits at $0.1 \%$ dietary inclusion level than at other levels.

The protein efficiency ratio of rabbits fed varying dietary levels of CPFM was significantly higher in rabbits fed $0.3 \%$ CPFM (1.82) and was lowest for rabbits fed diet with $0.1 \%$ CPFM (1.39) meaning that at $0.3 \%$ dietary CPFM, the animals' ability to utilize the protein contained in their feed for body building process is higher than at $0.1 \%$ dietary level. This could also be linked to better protein digestibility as observed in this study (Table 3 ) where digestibility of protein increased with increasing levels of Cameroon pepper in rabbits diet from those on control diets $(77.75 \%$ ) to $84.54 \%$ in those fed $0.3 \%$ dietary CPFM. Jang et al., (2004) and Sirinivasan, (2007) also reported that Capsaicin, the active ingredient in pepper has properties that include stimulation of digestive enzymes, saliva, hydrochloric acid and mucus; anti-oxidation effect, ability to improve the number and height of villi, reduction in crypt depth, anti-flatulence ability and anti-microbial activity. The presence of protein in feeds of animals is very important hence, feeds with some concentration of Cameroon pepper is recommended as evidenced in this study.

Metabolizable energy intake (MEI) of the rabbits reduced as the concentration of CPFM in the diet increased. MEI decreased from $228.03 \mathrm{Kcal}$ at $0.1 \%$ dietary level of CPFM to $178.13 \mathrm{Kcal}$ in those fed diet with $0.3 \%$ CPFM signaling a reduction in the feed intake with increase in the digestibilities of feeds' dry matter and nutrients (protein, oil, fibre and possibly minerals) by the rabbits. MEI sharply increased with $0.1 \%$ Cameroon pepper and dropped as the concentration of Cameroon pepper increased to 0.2 and $0.3 \%$ showing a significant $(\mathrm{p}<0.05)$ difference from the control. It follow the trend of feed intake.

The cost of feed per $\mathrm{kg}(\mathrm{N} 109.07-111.46)$, protein efficiency ratio $(1.39-1.82)$ increased from the control $\operatorname{diet}(\mathrm{TI})$ to treatment $4(0.3 \% \mathrm{CPBD})$ as the levels of Cameroon pepper increased in the diets. Cost of FI per $\mathrm{kg}$ BWG decreased significantly for rabbits fed beyond $0.1 \%$ dietary CPFM and the least/most economical value (N710.74) was obtained for rabbits fed diet with 0.3\% CPFM. Afolabi et al., (2017) obtained the same trend of decrease in the cost of feed intake per kg BWG as the level of hot red pepper increased in broiler's diet.

The best performance was obtained for rabbits fed 0.3\% dietary CPFM (T4) that had the highest value for weight gain, final body weight, protein intake, protein efficiency ratio and efficiency of feed utilization with a corresponding least value for feed conversion ratio and cost of feed per kg body weight gain. The result obtained corroborates the earlier reports (Afolabi et al, 2017; El-Tazi, 2014; El-Deek et al., 2012; El-Husseiny et al., 2002) who obtained a better performance and a higher net profit in broilers fed diets with hot red pepper over those on control diet without the pepper. Cameroon pepper can therefore be considered as a potential growth promoter in rabbits. 
Table 2: Growth Performance and economy of Rabbits fed varying dietary levels of CPFM

\begin{tabular}{llllll}
\hline Treatments & $\mathbf{1}$ (control) & $\mathbf{2}$ & $\mathbf{3}$ & $\mathbf{4}$ & SEM \\
Levels of CPFM (\%) & $\mathbf{0}$ & $\mathbf{0 . 1}$ & $\mathbf{0 . 2}$ & $\mathbf{0 . 3}$ & \\
\hline Parameters: & & & & & \\
Initial body weight (g) & 846.67 & 916.67 & 803.33 & 836.67 & 14.88 \\
Daily Feed intake/Rabbit (g) & $75.95^{\mathrm{ab}}$ & $89.07^{\mathrm{a}}$ & $69.10^{\mathrm{b}}$ & $69.59^{\mathrm{b}}$ & 3.21 \\
Daily wt. gain/Rabbit (g) & 8.76 & 9.15 & 8.67 & 10.99 & 0.57 \\
Final Body weight/Rabbit(g) & 1582.71 & 1685.47 & 1531.33 & 1760.03 & 47.72 \\
FCR & $8.80^{\mathrm{ab}}$ & $9.98^{\mathrm{a}}$ & $8.09^{\mathrm{ab}}$ & $6.38^{\mathrm{b}}$ & 0.42 \\
Efficiency of Feed Utilization & 0.12 & 0.13 & 0.13 & 0.16 & 0.03 \\
Cost of FI/Rabbit(N) & $696.86^{\mathrm{ab}}$ & $820.05^{\mathrm{a}}$ & $644.70^{\mathrm{b}}$ & $651.47^{\mathrm{b}}$ & 28.78 \\
Daily protein Intake (\%) & $12.58^{\mathrm{ab}}$ & $14.75^{\mathrm{a}}$ & $11.45^{\mathrm{b}}$ & $11.52^{\mathrm{b}}$ & 0.53 \\
Protein Efficiency Ratio (\%) & $1.49^{\mathrm{ab}}$ & $1.39^{\mathrm{b}}$ & $1.59^{\mathrm{ab}}$ & $1.82^{\mathrm{a}}$ & 0.07 \\
ME Intake/rabbits(Kcal) & $194.44^{\mathrm{ab}}$ & $228.03^{\mathrm{a}}$ & $177.12^{\mathrm{b}}$ & $178.13^{\mathrm{b}}$ & 8.22 \\
Cost of FI/kg BWG(N) & $959.81^{\mathrm{ab}}$ & $1093.81^{\mathrm{a}}$ & $897.79^{\mathrm{ab}}$ & $710.74^{\mathrm{b}}$ & 56.14 \\
Cost of feed per kg (N) & 109.07 & 109.60 & 110.93 & 111.46 & - \\
\hline
\end{tabular}

SEM = Standard Error Mean, $\mathrm{CPFM}=$ Cameroon pepper fruit meal, FI = Feed intake; FCR $=$ Feed Conversion Ratio, $\mathrm{BWG}=$ Body weight gain. $\mathrm{ME}=$ Metabolizable energy.

The digestibility of nutrients by rabbits fed varying dietary levels of CPFM is as shown in table 3 below. Digestibility of dry matter $(43.31-50.85 \%)$, ether extract $(81.36-83.69 \%)$ and crude fibre $(55.69-63.11 \%)$ were similar across treatments, meaning that Cameroon pepper had no significant effect on their digestibility in weaner rabbits. Digestibility of protein $(77.75-84.54 \%)$ however was significantly different. Digestibility of CP in rabbits on control diet (Treatment 1 ) and diet with $0.1 \%$ CPFM were similar just as those on $0.1-0.3 \%$ dietary CPFM were also similar. The CP digestibility in rabbits fed diets with 0.2 and $0.3 \%$ CPFM were significantly higher than what obtained for these on control diet without CPFM, meaning that Cameroon pepper increased the digestibility of protein in grower rabbits, hence the increasing protein efficiency ratio from 1.49 to 1.82 . Sirinivasan, (2007) reported that the active ingredient in pepper (Capsaicin) has properties that include stimulation of digestive enzymes, saliva, hydrochloric acid and mucus; anti-oxidation effect, ability to improve the number and height of villi, reduction in crypt depth, anti-flatulence ability and anti-microbial activity that can aid digestion and absorption of nutrients into the animal body.

Table 3: Digestibility of nutrients by rabbits fed varying dietary levels of CPFM

\begin{tabular}{llllll}
\hline Treatments & 1 (control) & 2 & 3 & 4 & SEM \\
Levels of CPFM (\%) & 0 & 0.1 & 0.2 & 0.3 & \\
\hline Parameters (\%): & & & & & \\
Dry Matter & $43.31^{\mathrm{b}}$ & $47.71^{\mathrm{a}}$ & $49.79^{\mathrm{a}}$ & $50.85^{\mathrm{a}}$ & 0.99 \\
Crude Protein & $77.75^{\mathrm{b}}$ & $81.79^{\mathrm{ab}}$ & $84.08^{\mathrm{a}}$ & $84.54^{\mathrm{a}}$ & 1.11 \\
Ether Extract & 81.36 & 82.96 & 83.13 & 83.69 & 1.52 \\
Crude Fibre & 55.69 & 60.31 & 63.11 & 60.31 & 1.64 \\
\hline
\end{tabular}

SEM $=$ Standard error mean, $\mathrm{CPFM}=$ Cameroon pepper fruit meal.

\section{Conclusion}

- Feeding crossbred weaner rabbits up to $0.3 \%$ dietary Cameroon pepper fruit meal elicited optimum growth performance with the highest value for weight gain, final body weight, protein intake, digestibility of protein, protein efficiency ratio and efficiency of feed utilization; and a corresponding least value for feed conversion ratio and cost of feed per $\mathrm{kg}$ body weight gain.

\section{References}

1. Abu, O.A., Onifade A.A, Abanikande, O.J. \& Obiyan, R.I. (2008). Status of promotional strategies for Rabbit production in Nigeria. World - Rabbit Science, 9:1499-1502.

2. Afolabi, K.D., Ndelekwute, E.K. Alabi, O.M. and Olajide, R. (2017). Hot Red Pepper (Capsicum annum L.) Meal Enhanced the Immunity,Performance and Economy of Broilers Fed in Phases. Journal of Biology, Agriculture and Healthcare. Vol 7(8): 1-7.

3. Al-Kassie, G.A.M., Al-Nasrawi, M.A.M. \& Ajeena, S.J. (2011). The Effects of Using Hot Red Pepper as a Diet Supplement on Some Performance Traits in Broiler. Pakistan J. Nutr. 10(9):842-845.

4. AOAC. (2005). Official Methods of Analysis of the Association of Analytical Chemists International. $18^{\mathrm{TH}}$ Edn., Gathersburg, MD U.S .A. Official Methods, August.

5. Bosland, P.W. (1996). Capsicums: Innovative Uses of an Ancient Crop. In: Janick J editor. Progress in new crops. USA: ASHS Press; 1996:479-487. 
6. Carlos, E.S., Monteiro, T.N., Santana, P. \& Karina, P.C. (2011). "Reproductive characterization of interspecific hybrids among Capsicum species" Brazilian Society of Plant Breeding. Crop Breeding and Applied Biotechnology, 11: 241-249.

7. Das, J., Deka1, M. \& Gogoi1, K. (2018). Antimicrobial Activity of Chilli Extracts (Capsicum chinense) Against Food Borne Pathogens Escherichia coli and Staphylococcus aureus International Journal of Research and Analytical Reviews (IJRAR), 5(4):717-720., www.ijrar.org

8. El-Deek, A.A., Al-Harthi, M.A., Osman, M., Al-Jassas, F. \& Nassar, R. (2012). Hot pepper (Capsicum Annum) as an alternative to oxytetracycline in broiler diets and effects on productive traits, meat quality, immunological responses and plasma lipids. European Poult. Sci. (Arch.Geflügelk). 76(2):S.73-80.

9. El-Hussainy, O., Shalash, S.M., \& Aziuz, H.M. (2002). Response of broiler performance to diets containing hot pepper and/or fenugreek at different metabolizable energy levels. Egyptian Poultry Science 11:387-406.

10. El-Tazi, S.M.A. (2014). Response of broiler chicks to diets containing red hot pepper as natural feed additive. Journal of Science and Technology, 4(5):81-86.

11. Fattori, V., Hohmann, M.S., Rossaneis, A.C. (2006). Capsaicin: Current Understanding of Its Mechanisms and Therapy of Pain and Other Pre- Clinical and Clinical Uses. Molecules, 21 (7):E844. 1795-1803.

12. Hencken, H., (1991). Cooling the burn from hot peppers. Journal of the American Medical Association, 266:2766- 2770 .

13. Jang, I.S., Ko, Y.H., Yang, H.Y., Ha, J.S., Kim, J.Y., Kang, S.Y., Yoo, D.H., Nam, D.S., Kimand, D.H. \& Lee, C.Y. (2004). Influence of essential oil components on growth performance and the functional activity of the pancreas and small intestine in broiler chickens. Asian - Aust.J. Anim. Sci. 17; 394 - 400.

14. Kraft, K.H., Brown, C.H. \& Nabhan, G.P. (2014). Multiple lines of evidence for the origin of domesticated chili pepper, Capsicum annum, in Mexico. Proc Natl Acad. Sci. USA. 2014; 111 (17):6165-6170.

15. Lv, J., Qi, L., Yu, C., Yang, L., Guo, Y. \& Chen, Y., (2015). Consumption of spicy foods and total and cause specific mortality: Population based cohort study. BMJ (clinical research ed). 2015;351:3942.

16. Macho, A., Lucena, C., Sancho, R., Daddario, N., Minassi, A., Munoz, E., \& Appendino, G. (2003). Nonpungent capsaicinoids from sweet pepper synthesis and evaluation of the chemopreventive and anticancer potential. Eur. J. Nutr., 42:2-9.

17. Materska, M. and Perucka, I. (2005). Antioxidant activity of the main phenolic compounds isolated from hot pepper fruit (Capsicum annum 1.). J. Agric. Food chem., 53:1750-1756.

18. Ndelekwute, E.K., Afolabi, K.D., Uzegbu, H. D., Unah, L.U. \& Amaefule, K.U. (2015). Effect of dietary Black pepper (Piper nigrum) on the performance of broiler. Bang. J. Anim. Sci. 2015. 44 (2): 120-127.

19. Oguike, M.A. and Ohaja, A. (2009). Effect of different protein sources on the reproductive performance of Rabbit does. Proceedings of 34th Annual conference of Nigerian Society for Animal Production, University of Calabar, Calabar, pg. 192-193.

20. Omolo, M.A., Wong, Z., Mergen, M.A., Hastings, J.C., Le, N.C., Reiland, H.A., Kyle, A.C. \& Baumler, D.J. (2014). Antimicrobial properties of chili peppers. Journal of Infectious Diseases \& Therapy, 2(4):2-8.

21. Pawar, S.S, Bharude N.V. \& Sonone S.S, (2011). Chilies as food, spice and medicine: A perspective. International Journal of Pharmacy and Biological Sciences, 1(3):311-318.

22. Rodriguez, B.A., Kollmannsberger, H. \& Prohens, J. (2010). Comparative analysis of pungency and pungency active compounds in Chile peppers (Capsicum ssp.). Bull UASVM Horticulture, 67 (1):270-273.

23. Sancho, R., Lucena, C., Macho, A., Calzado, M.A., Blanco-Molina, M., Minassi, A., Appendino, G. \& Muñoz, E. (2002). Immunosuppressive activity of Capsaicinoids: Capsiate derived from sweet peppers inhibits $\mathrm{Nf}-\mathrm{Kb}$ activation and is a potent anti-inflammatory compound in vivo. European Journal of Immunology, 32:1753-1763.

24. Sirinivasan, K. (2007). Black pepper and its pungent principle - piperine. A review of diverse physiological effects. Food Science and Nutrition, 47 (8):735-748.

25. SPSS. (2013). Statistical Package for Social Sciences. Windows release 22 version. SPSS Inc 1989-2013 Copyright SPSS Inc. Headquarters, 233 S Wacker Drive, Chicago, Illinois 60600.

26. Wahba, J. (2014). Return migration and economic development. International handbook on migration and economic development, Chapter: 12, publisher: Edward Elgar Publishing Ltd, editors: Robert E.B. Lucas.

27. Mônica Rosa Bertão, 1 Milena Cristina Moraes, Darío Abel Palmieri, Luciana Pereira Silva \& Bertão, M.R., Moraes, M.C., Palmieri,,D.A., Silva, L.P. and Gonçalves da Silva, R.M. (2016). Cytotoxicity, Genotoxicity and Antioxidant Activity of Extracts from Capsicum spp. Research Journal of Medicinal plants, ISSN 18193455., DOI: 10.3923/rjmp.2016 